\title{
USDA clarifies practice for certain adjudicatory proceedings
}

On 12 May, the USDA amended the administrative regulations of the Office of the Secretary of Agriculture to "provide that the rules of practice contained in those regulations shall be applicable to all adjudicatory proceedings under the license denial and termination provisions of the Animal Welfare Act (AWA) regulations ${ }^{1}$."

Sec. 2.11(a) of this act describes the conditions under which a person applying for a license to operate as a dealer, exhibitor, or operator of an auction sale of animals may have their application denied. The following sections describe the rights of applicants to contest a denied application or terminated license. According to these regulations, a person whose license application has been denied, or whose license has been terminated "may request a hearing in accordance with the applicable rules of practice for the purpose of showing why the application for license should not be denied or the license should not be terminated. This final rule is necessary to clarify the rules of practice that will apply to such hearings ${ }^{1}$."

To clarify which rules of practice apply in Sec. 2.11(b) and Sec. 2.12 of the AWA, the USDA amended the administrative regulations of the Office of the Secretary in 7 CFR part 1 , subpart $H$, 'Rules of Practice Governing Formal Adjudicatory Proceedings Instituted by the Secretary Under Various Statutes' (7 CFR 1.130 through 1.151). Specifically, Sec. 1.131, 'Scope and applicability of this subpart', was amended to provide that the rules of practice contained in this subpart $\mathrm{H}$ will apply to all adjudicatory proceedings as described in the license denial and termination provisions of Sec. 2.11 and Sec. 2.12.

1. USDA APHIS. Final rule. Rules of practice for certain adjudicatory proceedings under the Animal Welfare Act Regulations. Federal Register 70(91), 24935-24936 (12 May 2005).
REGULATION UPDATES

\section{California starts web animal database to locate endangered species}

On 17 May, California started a new web resource-Pesticide Regulation Endangered Species Custom Realtime Internet Bulletin Engine (PRESCRIBE) - for tracking the habitat of endangered species throughout the state ${ }^{1}$. The Department of Pesticide Regulation, which created the PRESCRIBE online database application, says that this tool was "developed to help pesticide applicators find out if they have any endangered species in the vicinity of their application site, and the use limitations applicable to the pesticide product(s) they intend to use $\mathrm{e}^{2}$."

1. Department of Pesticide Regulation. DPR now PRESCRIBEs protection for endangered species. (17 May 2005). http://www.cdpr.ca.gov/docs/pressrls/2005/050517.htm.

2. Department of Pesticide Regulation. PRESCRIBE online database application. http://www.cdpr.ca.gov/docs/es/ prescint.htm.

\section{European court dismisses French action against ban on animal testing for developing and marketing cosmetics}

On 24 May, the Court of Justice of the European Communities dismissed the French request to partially annul Directive 2003/15/EC1, which provides that "Member States are to ban progressively the marketing of cosmetic products in cases where those products or their ingredients have been

the subject of animal testing and the performance, within their territory, of testing on animals in respect of such products or ingredients. The directive also sets aside the ban on marketing of those products provided for hitherto by Directive 76/768 (ref. 1)." France argued that the court bans of Directive 2003/15 infringed the principle of legal certainty.

The European court deemed the French action to be inadmissible, concluding that the "partial annulment sought was impossible," because it "would substantively alter the provisions relating to testing on animals for the purpose of developing cosmetic products ${ }^{1}$."

1. Luxembourg: EU Court annuls action against ban sought on animal testing for developing \& marketing cosmetics.

World of Garment-Textile-Fashion. (25 May 2005). http://www.fibre2fashion.com/news/NewsDetails.asp? News_id=15643. 